\title{
Foregrounding social justice in mathematics teacher education
}

\author{
Peter Gates · Robyn Jorgensen (Zevenbergen)
}

Published online: 12 May 2009

(C) Springer Science+Business Media B.V. 2009

This is the first of two Special Issues on social justice and mathematics teacher education in 2009. This first issue is subtitled as Theoretical Studies in Social Justice whilst the second, which appears in the next issue, is subtitled as Case Studies in Social Justice.

One justification for the two special issues is the considerable international interest in social justice around the world. It is a key plank of many governments' strategies and similarly various international organisations have social justice and inclusion as a fundamental policy objective.

In particular in many parts of the world the link between social class and educational attainment is a key and central concern for educators, researchers and policymakers. Within the wider educational and sociological literature as well as within policy discourses there is an interest in the social context of learning and a recognition that we cannot be socially just merely by assuming everyone be treated equally. There is a further recognition which brings this much closer to the concerns of this Journal-recognition that somehow schooling exacerbates social immobility, and reinforces current social stratification and social exclusion of marginal groups. It is further widely recognised that mathematics teaching in schools play a significant role in the positioning of pupils and in their developing identities as learners and citizens - and references here are almost too legion to cite.

This journal has been in existence only since 1998 and one might expect a journal dedicated to teacher education in a discipline with a rich literature on social class and social justice would have this topic as fairly central to its concerns; surprisingly this has not been the case. The first Special Issue of JMTE appeared in 2003 in Volume 6 on Teams and Networks, and in that issue, the editorial by Konrad Krainer stressed the "increasing awareness of the social dimension in mathematics education" (p. 93). That issue focussed, however, on the social as social interaction, though it did have an article by Renuka Vithal looking at prospective mathematics teachers and street children. Since that issue there has arguably been only one article in JMTE addressing social justice-by Helen Forgasz in

P. Gates $(\bowtie)$

University of Nottingham, Nottingham, UK

e-mail: peter.gates@nottingham.ac.uk

R. Jorgensen (Zevenbergen)

Griffith University, Brisbane, Australia 
2006, Vol. 9, No. 5 (Computers, Equity and Computers for Secondary Mathematics Learning). This is quite surprising - but we are not criticising the Journal or its editors for ignoring social justice issues, nor for reluctance to publish articles in that field. Rather we suspect that this reflects the fact that few articles have been submitted which might raise some questions about the place of social justice within mathematics teacher education. However, the invitation to us to produce a special issue is a clear attempt to put that right and we congratulate JMTE for recognising the important contribution that understanding the relationship between social justice and mathematics teacher education can make to the literature — and we thank the editor for the opportunity. These two Special Issues are quite timely.

Mathematics and social justice has been the focus of much research-however, this has largely focussed on such issues as the process of learning, the content of the curriculum and its assessment. Possibly rather less has focussed on issues for teacher educators. The challenge for us in putting together this Special Issue was to relate two key themes-on the one hand a social justice perspective and on the other, the professional development of mathematics teachers. This has not been easy and there were a number of proposals which we had to reject because they did not position themselves in that nexus. For example, we did not accept articles that claimed to offer a socially just curriculum in a teacher education programme that purported to make an improvement for all learners. So we needed evidence that the focus in articles was in some way aimed at alleviating the position of the most disadvantaged groups - and to take that to its logical conclusion this really has to be at the expense of the already advantaged; we cannot reduce social injustice by merely giving everyone a chair to stand on. Already there is some suggestion that many current attempts at reducing social exclusion, do improve the situation for the most marginalised, yet at the same time do an even better job for the most affluent leaving the gap even wider. We sought articles that reduced this gap.

However, even that stance presented us with very diverse perspectives across the articles in these two Special Issues. Some articles focus on teacher development for social justice looking at pupils as excluded in the classroom, whereas others look at teacher education for social justice by looking at groups of teachers who are themselves seen as excluded groups. However, the eight articles cover a broad range of perspectives which we hope will mark out some of the territory for years to come.

We start by saying something about the creation of the Special Issues on social justicewhich we were invited to consider in mid-2007. There were several key principles. First the articles needed to cover both the field of mathematics teacher education and have a social justice perspective. This was not always easy because there were sometimes quite different expectations of what "social" meant as well as what "justice" implied and we had several discussions with some authors on both those points.

Secondly, we wanted both an international editorial team (Gates-UK, Jorgensen-Australia, Civil-USA and Matos-Portugal) as well as an international group of authors and reviewers (Denmark, New Zealand, Australia, Portugal, Australia, Canada, USA, UK and Spain). However, we are not oblivious to the obvious geographical and socio-political blind-spots in that list but therein lies another story.

Thirdly, all reviewing for the Special Issues themselves would need to be socially just; this was non-negotiable. To achieve this we saw some key human values as central elements: honesty, openness and humility. Such values can only be achieved in an atmosphere of mutual trust and respect and so reviewing would need to be doubly open and transparent; all reviewers knew the names of all the authors whose work they were reviewing and authors knew the names of all their reviewers. This was one way in which the 
academic process itself could be made socially just. All authors and reviewers knew this in advance and no objection or concern was raised at all and it bought only advantages; in particular it has enhanced the quality of reviewing but also the quality of the articles you are about to read. Subsequently, we have been able to present eight articles that eventually went to make up not one but two Special Issues - and we are most grateful to all authors and reviewers for their contributions and patience. It is perhaps also significant that, naturally, all authors, editors and reviewers were themselves committed to social justicethough we might well ask just what that means. So in order to set the scene, we will start with a brief discussion on what is, or might be understood by, social justice and how one might examine the theoretical aspects behind what can be a way of talking about relational issues of justice.

\section{Theorising social justice in mathematics teacher education}

In coming to understand what is meant by social justice in the field of mathematics teacher education, we will draw on Bourdieu's work to consider how relations of power, access and equity are lived in and through social practice. In this Special Issue, the practice being spoken of is mathematics education but as can be seen in the collection of articles in this issue and the subsequent Special Issue, the various authors take the notion of practice from a range of different perspectives that can include teacher-student interactions in classrooms through to teacher education programs. This diversity of practice enriches our notions of mathematics education. However, as can be seen in this collection, the issues of power that are fundamental to a conception of social justice are varied and multi-faceted and this is represented in the rather different perspectives of the various authors.

In this editorial then we want to open up for readers the theoretical framings through which the authors tackle social justice and in order to do that we have to have some way of framing the theoretical underpinning which link the articles. Drawing on the work of Pierre Bourdieu, we will explore the notion of social justice at the intersections of practice, habitus and field.

Through primary and secondary socialisation, people come to constitute a habitus which for Bourdieu is an enduring set of dispositions, habitual behaviours that predispose a person to act and see the world through particular lenses. Thus, the habitus of a workingclass lad or a middle-class yuppie will provide nuances for the learner as he or she enters the worlds of school mathematics-either as a student, pre-service teacher or teacher. This habitus renders the world to particular viewings that shape, and are shaped by, the participant. For Bourdieu, the habitus may be enduring but it is not fixed; it can be shaped so that, over time, as practices change, so can the habitus. For working-class students, coming into school mathematics with the habitus of the working-class, their predispositions facilitate different ways of acting and being in the classroom compared to their peers from middle-class backgrounds. What is fundamental to Bourdieu's project is that for some students, the closer synergy between the habitus with which they enter the classroom and the expected practices of the school will render their potential for success as much greater than pupils where there is a greater degree of conflict. In other words, pupil success depends on the degree of commonality between the field of school mathematics and the habitus of the learner or participant. For example, the language that is part of the workingclass habitus has less synergies with school mathematics than the middle-class register (Zevenbergen 2000) so that learning mathematics requires some students to reconstitute their linguistic habitus to align with that of school mathematics. In contrast, middle-class 
learners whose habitus aligns more closely with that of the register of school mathematics are more likely to engage with specific formulations of mathematical ideas and process due to the pedagogic relay being closely aligned with their home language. Thus, the field, in this case school mathematics, in which the participants engage recognises and conveys power to those whose habitus is represented and privileged in that field.

The ways in which power over particular groups can be exercised is through both objective structuring practices and subjective structuring practices (Zevenbergen 2005). The objective structuring practices are those such as assessment or curriculum in which cultural forms are manifested and seen to be normalised. For students who sit assessment tasks, such as English-based examinations where their first language maybe is an Indigenous language, the test is somewhat more difficult, thus making success more elusive. Yet, the scores on the examination are seen to be a representation of some innate abilitysomething Bourdieu terms misrecognition. Thus, the objectification of cultural forms through the objective structuring practices of school mathematics enables some students greater access to the forms of capital available within the field (Bourdieu 1983). These may be grades or scores, through to awards or merely being allocated into the higher streams of mathematics teaching groups.

Of more subtle and coercive forms, the subjective structuring practices (Bourdieu 1977) are where learners internalise practices as if they were inherent within the individual. For example, internalising the poor performance on mathematics tests so as to be in the lower streams of school mathematics, learners were found to speak of themselves as failures (Zevenbergen 2003) thus having low expectations of themselves, expecting to have poor teachers and so on. Thus, the internalisation of such practices now becomes a subjective way of interpreting actions.

Research has consistently cast doubts over the advantages of setting and streaming in mathematics yet within the field of mathematics education, it is a widespread common and almost universal practice. A social justice perspective on teacher education would ask here how teacher education plays a part in the furtherance of a practice which evidently works against the interests of many learners. Significantly, such socially unjust practices are not imposed upon teachers; they are enacted by them, and believed by them to be essential and natural. This is why the issue of social justice should be such an important concern for readers of this journal.

In these two Special Issues, some contributions (Elizabeth de Freitas in Issue 1 and Mark Boylan in Issue 2) look critically at mathematics teacher educators and how they might engage with prospective teachers. In both cases the authors can be seen as offering strategies to teacher educators to perturb the misrecognition underway in mathematics teaching - albeit from quite different perspectives. We are expecting some of this to be controversial; working for social justice is no tea party.

When using Bourdieu's theoretical ideas to understand social justice in mathematics education, the practices within the field come under close scrutiny in order to examine the ways in which power is enacted and the consequences of such acts. For Bourdieu, the act of symbolic violence (Bourdieu 1979, p. 302) is one where the processes of domination are made possible through the shared doxa of the dominant and dominated whereby both parties approve and reward practices within a field. For example, for mathematics to be enabled to create classes of haves and have nots, then participants must buy (almost unquestioningly) into the legitimacy of the practices. This is often seen through the acceptance that mathematics represents objectivity and impartiality that is not apparent in other fields of education. This assumption enables participants to buy into the belief that those who are successful do so as an apolitical act of their inherent worth. This enables the 
dominant to retain their position of power while the dominated remain ignorant of their oppression. The act of symbolic violence remains powerful when those complicit in the act remain oblivious to the outcomes of the oppression.

This leads us then to consider, why, if social justice is of such inherent worth, we still need to write about it and have a Special Issue; is it not then like apple pie and motherhood - of such intrinsic worth all have to line up under its banner. There are some in this issue who illustrate why that is not the case-Ole Skovsmose for example.

\section{What is social justice?}

The connection between social class and educational underachievement is not a recent concern, though in the UK it has impacted significantly on the government policy agenda since "New" Labour came to power in 1977. One might hope that with left-leaning governments in so many countries around the world, social justice might be now so firmly on political agendas that we would start to see radical changes. However, Reay et al. (1995) suggest that far from getting better, social injustice measured through a deepening of educational and social stratification is actually getting worse.

The publication of these two Special Issues is testimony to the continued concern in the mathematics education community over the problems of social justice, and the real need to bring it to the attention of mathematics teachers. However, we do need to ask-why has it taken so long? Why isn't everybody—or at least more people-concerned about social justice?

The first challenge is perhaps to come up with a definition of social justice with which we can all agree. Reading the articles in this and the next Special Issue will very quickly show that social justice is difficult to define, in part because it not only depends on one's own world view, but also it depends somewhat on the situation being analysed. Social justice is a relative concept; what is unjust to some, is not unjust to others; whether we consider something is socially unjust or relationally unjust will likewise differ.

What might we all agree on then as fundamentals of a socially just mathematics education? Perhaps we can list: access to the curriculum; access to resources and good teachers; conditions to learn; and feeling valued. How about the following as basic rights for learners of mathematics? The right to go to university or become a professional mathematician irrespective of one's parental income or education? The right to space and conditions in the home to study? The right to a computer at home? The right to be fed well enough to concentrate on learning?

We could, of course, continue this staged process of human rights until we reached a point where most people would presumably claim that was not the responsibility of a mathematics education. Surely few would claim that the social conditions of our pupils were not our concern. Yet, we claim that is exactly what does happen in the field of mathematics teacher education - to a great extent. The article by Ole Skovsmose in this first Special Issue reminds us of these features which influence learning of our pupils.

Research in education and in mathematics education has already shown how the subject discipline (and that word itself is not a mere accident of history) contributes to the construction of the subject. Is it enough to claim we support social justice without a passion and a vision for how it could be different?

In this article, we want to offer a framework around which we can begin to talk about the extent to which practices and conditions are socially just. We use the term social justice for a reason; we do not simply use the words fair or equitable. 
Here is not the place for a full critique of the notion of social justice since the literature is so vast and our purpose is to focus on social justice and mathematics teacher education. However, we might start way back with John Rawls' ideas for justice (Rawls 1971). In contrast and critique, Wolff (1977) argued that Rawls' construction did little to challenge the structural forms and practices - the status quo-which resulted in the very injustice that Rawls tried to counter. So even here, we can see the problem. Whereas all of us would surely claim to want social justice-what form of social justice do we want?

So why is this important for mathematics teacher education? Again we will not repeat the vast literature on this but will let Paul Ernest speak:

Mathematics has been remarked upon as playing a special role in sorting out students and preparing them for and directing them to different social stations. ... Indeed, Sells (1978) coined the term critical filter for this social function of mathematics. Thus, the teaching and learning of mathematics seems to occupy a special place in the provision of social justice-or its obstruction-within the education system. (Ernest 2007, p. 3)

More on the relationship between mathematics education and social justice can be found in issues 20 and 21 of the on-line Philosophy of Mathematics Education Journal (http://people.exeter.ac.uk/PErnest/pome20/index.htm and http://people.exeter.ac.uk/PErnest/ pome21/index.htm) and we will not duplicate that here.

Why is defining social justice so difficult then? We claim this is because social justice is a social process and an ideological process-and we engage with it as social and ideological agents. We engage with ideas of social justice in the same way we engage with ideas about God, politics and football. These are ideological stances. Ernest asked the question "why do some individuals believe in social justice?" (Ernest 2007, p. 3) opening up the possibility that some people do not. He goes on to speculate on six reasons why there is "divergence in interest and commitment to social justice amongst mathematics educators" (p. 3). Gates argued that mathematics teachers-and we would extend this to teacher educators and academics- "do not come to the classroom devoid of social and political motives and intentions" (Gates 2006, p. 350).

At the risk of oversimplifying the problem of definition, we want to offer a three level operational framework for how we can understand the diverse ways in which social justice is being constructed as an ideological field. This framework, however, is an act of that very ideological field so we do not expect it to be treated as anything different.

\section{Moderate forms of social justice}

Moderate forms of social justice are probably the easiest to sign up to. They focus on fairness and equity. However, they tend to presume the continuance of the status quo, and do not explicitly recognise or relate to structural inequalities in society, which lie at the root of social injustice; they certainly do not challenge the existence of the status quo. Work in this tradition might typically work on classroom relationships, language, and assessment.

This form of social justice might easily be signed up to or even hijacked by neoconservatives, who recognise inequality but who want to avoid a questioning of the difficult social conditions which bring it about and the and potentially threatening challenges required to bring about change. 


\section{Liberal forms of social justice}

The next form of social justice is slightly more demanding. This does recognise structural inequalities and does address those in some way. However, underlying this work is an acceptance that classrooms can be made more just within the existing structures. Liberal forms of social justice see relationships as a key feature in classroom interaction, and may go further and see a classroom as the main social organ. It would see this level as political because human life operates at the individual level and this is where power itself operates. Hence the classroom becomes a political arena and politics is produced at the level of the individual in a small community. For example, it would see the politics of gender relationships and identities as constructed within classrooms.

There is a trend in mathematics education research, which we suspect sees itself within a social justice tradition, rightly so, but which places trust and significance in language and words. Sometimes - and for reasons of professional ethics we restrain ourselves from specific citation - this results in research based on the assumption that we only need to look at language or discourse as roots of oppression-which is only the case within a particular-liberal-form of social justice. This is a bit of a difficult one, as it brings us to Foucault and post-structural accounts of power. However, we are placing both Foucault and post-structuralism within the liberal tradition.

\section{Radical forms of social justice}

The third form of social justice recognises structural inequality and seeks to redress the ways in which inequality is built into existing practices. By changing these structures greater access to, and success with, mathematics can be possible for those groups of students who have been excluded from participating in mathematics. The structures may be both objective and subjective but are frequently internalised by participants as being normal parts of the social order. This enables the production of a stratified society without anarchy, where social groups come to accept their place in the social hierarchy as a normal outcome. One powerful way in which this is achieved is through notions of ability where, for example, class differences come to be framed as differences in ability. This is then reified in pedagogical practices of ability grouping, which as Apple has contended, are where the different 'ability groups' can be seen to be manifestations of classed differences. A radical view of social justice seeks to disrupt the ideology and change the practices that create and support structural inequities.

Radical forms of social justice are somewhat more demanding politically (and emotionally) because they recognise relational inequality and structural inequality, social class and ideology.

Such a position is characterised by Marylyn Frankenstein:

So, I argue that mathematics education in general, and mathematics in particular, will become more equitable as the class structure in society becomes more equitable. Since I also contend that working-class consciousness is an important component in changing class inequities, developing that consciousness during teaching could contribute to the goal of ensuring equity in mathematics education. ... I think that mathematical disempowerment impedes an understanding of how our society is structured with respect to class interests. (Frankenstein 1995, p. 165) 
The radical form of social justice is probably the only form in which one can freely use the term "working class consciousness" and get away with it. Such class inequities go to the heart of radical perspectives on social justice as Paola Valero describes it.

The existence of deep class inequalities in society that are also present in school and that permeate the way in which mathematics is taught. Students' awareness of these class inequalities is essential in a move towards a more equitable society. Mathematics education (of certain kind) can help students gaining class-consciousness since it can make visible the way in which mathematical calculations are implicated themselves in the production of those inequalities. Mathematics education empowers students to gain this awareness. A lack of mathematical capacities-mathematical disempowerment—blocks the gaining of class consciousness. (Valero 2007, p. 7)

Two of the key parameters in this form of social justice are "class inequalities" and "class consciousness"; and the recognition of these probably lies at the heart of what makes this form of social justice more challenging to many.

\section{Overview}

There are strengths and dangers in each of these three positions - and even in the attempt at segregating out the various forms but we would claim the continued interest in social justice and the increasing gap between the affluent and the marginalised, requires us to do more to get to grips with the continuance of oppression. Mathematics education has been for a long time a conservative field and a push for social justice is a call to change the field. These two Special Issues are an attempt to begin changing the field through mathematics teacher education-through eight papers which offer us a variety of perspectives and a variety of challenges.

\section{The articles in this issue: theoretical studies in social justice}

In "Using social semiotics to prepare mathematics teachers to teach for social justice", Elizabeth de Freitas and Betina Zolkower explore the connection between mathematics and culture politics. Using social semiotics they offer a refreshingly detailed presentation of how language and domination can be raised with prospective teachers. Drawing on both the approach of Bourdieu and semiotics and pulling these together quite innovatively, they represent a political stance that recognises structural inequality and the sources of that inequality. They look at deconstructing classroom discourse to explore the intimate connexions between the instructional discourse of mathematics and the regulatory discourse of the classroom.

This is important because it challenges teachers and teacher educations to recognise their own culpability — though perhaps largely unintentional-in the reproduction of social structures.

In performing this analysis, Elizabeth and Betina help us explore the question-so how does mathematics teaching relate to social justice-here the claim is through the intersection and overlap between the instructional and regulatory discourses. However, it is more than this- to use a term though not an idea introduced by Bourdieu we see the misrepresentation of a regulatory discourse as an instructional discourse. 
Our second article is intriguingly entitled "How to drag with a worn-out mouse? Searching for social justice through collaboration". As we might expect from Miriam Pentiado and Ole Skovsmose they offer us a very direct political challenge by exposing a context in which economic disadvantage impacts directly upon children's educational progress. Social justice in mathematics teacher education cannot be a "soft option" for Miriam and Ole and they set out to fight a very well established structure of systematic disadvantage. Yet too often such attempts fall into the silences of mathematics education literature-and we would argue particularly in the mathematics teacher education literature.

Here Miriam and Ole begin to politicise social justice through the availability of ICT to empower mathematics learning. There is much written in mathematics education journals which focuses upon the content, processes and resources but which chooses to overlook the politics and the selectivity behind the selection of winner and losers. Will the computers be stolen? What if a student has never touched a mouse? What if, like most things in the school, the mouse is just worn out? Some learners-and it follows some teachers-never have to worry about such things as a worn out mouse as they have the best resources their parents' money can buy.

One issue we face in mathematics teacher education is in working to change teachers. Whilst there are some who say one cannot and ought not to change others, many of us committed to social justice cannot see an alternative. The challenge is in helping prospective teachers do what they would otherwise not do and think what they would otherwise not think. In "Mathematics In and Through Social Justice: Another Misunderstood Marriage?" Kath Nolan poses a really practical challenge for the mathematics teacher education community. Nolan puts it in this way: "On one level, they desired that complex social justice issues be reduced to some tips and techniques for the classroom teacher". If we give prospective teachers tips and techniques-are they theirs or ours. Do you live social justice or implement it; is it a process or a product? She argues that "directing students eyes towards a particular perspective is a power is a power issue, and that considerable didactic tension exists in directing students' eyes while, at the same time, promoting student agency and empowerment". Her article poses a question for us all-is the relationship between mathematics education and social justice a committed lifetime bound or simply a marriage of convenience?

In "Teaching for Social Justice: Exploring the Development of Student Agency Through Participation in the Literacy Practices of a Mathematics Classroom", Ray Brown documents an approach he has implemented in primary classrooms where he works within mainstream classrooms but changes his pedagogy. His approach is to change the ways in which students negotiate meaning. His liberal approach is one where he is seeking to include and enhance the learning of all students in his classroom. The approach, which he names as "Collective Argumentation" draws on the work of Vygotsky in particular, and seeks to engage learners in discussing mathematical ideas in ways that are both rich and deep. His paper draws on two cases (of girls) who develop a sense of agency in relation to their mathematical learning.

\section{The articles in the next issue: case studies in social justice}

In the next Special Issue on Social Justice we focus on case studies and look at four more aspects of social justice in mathematics teacher education. Núria Planas and Marta Civil write on working with mathematics teachers and immigrant students; Anna Llewellyn 
discusses choice, control and confidence through two case studies which explore power and identity; Tamsin Meaney, Tony Trinick and Uenuku Fairhall look at social justice and attendance of Maori teachers at a mathematics teacher conference. Finally Mark Boylan explores social justice through emotionality and mathematics teacher education.

However, it is our hope that the articles in these two Special Issues do more than present a theoretical perspective, or 'a set of lenses through which to understand social justice'. As one of us wrote in 2001:

Unfairness, injustice, and prejudice are not abstract concepts of some macro-social analysis of an internecine class war. They are felt through the disappointment, hopelessness and frustrations of ordinary people as they go through their everyday lives. (Gates 2001, p. 8)

We hope you enjoy all eight articles in the two Special Issues; we hope you feel challenged; and we hope some things change.

\section{References}

Bourdieu, P. (1977). Outline of a Theory of Practice (R. Nice, Ed., Trans., 1992). Cambridge: Cambridge University Press.

Bourdieu, P. (1979). Distinction. A Social Critique of the Judgement of Taste (R. Nice, Trans., 1984). London: Routledge.

Bourdieu, P. (1983). The forms of capital. In J. G. Richardson (Ed.), Handbook of theory and research for the sociology of education (pp. 241-258). New York: Greenwood press.

Ernest, P. (2007). Why social justice? Philosophy of Mathematics Education Journal, 21. Retrieved from http://people.exeter.ac.uk/PErnest/pome21/index.htm. Accessed 6 May 2009.

Frankenstein, M. (1995). Equity in mathematics education: Class in the world outside the class. In W. Secada, E. Fennema, \& L. Adajian (Eds.), New directions for equity in mathematics education (pp. 165-190). Cambridge, USA: Cambridge University Press.

Gates, P. (2001). What is an/at issue in mathematics education. In P. Gates (Ed.), Issues in mathematics teaching. London: Routledge Falmer.

Gates, P. (2006). Going Beyond Belief Systems: exploring a model for the social influence on Mathematics Teacher Beliefs. Educational Studies in Mathematics, 63, 347-369. doi:10.1007/s10649-005-9007-z.

Rawls, J. (1971). A theory of justice. Harvard, MA: Belknap Press.

Reay, D., David, M., \& Ball, S. (1995). Degrees of choice: class, race, gender and higher education. London: Trentham books.

Sells, L.W. (1978, February). Mathematics: critical filter. Science Teacher (Normal, Ill.), 28-29.

Valero, P. (2007). What has power got to do with mathematics education? Philosophy of Mathematics Education Journal, 21. Retrieved from http://people.exeter.ac.uk/PErnest/pome21/index.htm. Accessed 6 May 2009.

Wolff, R. P. (1977). Understanding rawls: A critique and reconstruction of a theory of justice. Princeton: Princeton University Press.

Zevenbergen, R. (2000). "Cracking the Code" of mathematics: School success as a function of linguistic, social and cultural background. In J. Boaler (Ed.), Multiple perspectives on mathematics teaching and learning. New York: JAI/Ablex.

Zevenbergen, R. (2003). Ability grouping in mathematics classrooms: A Bourdieuian analysis. For the Learning of Mathematics, 23(3), 5-10.

Zevenbergen, R. (2005). The construction of a mathematical habitus: implications of ability grouping in the middle years. Journal of Curriculum Studies, 37(5), 607-619. doi:10.1080/00220270500038495. 